\title{
CAMPURAN PAKAN HERBAL UNTUK TERNAK AYAM KAMPUNG (Mixture Herbal Woof For Livestock Chicken Local)
}

\author{
Nurhapsa $^{1}$, Yus riadi $^{2}$, Nurhae dah $^{3}$ \\ Universitas Muhammadiyah Parepare \\ ${ }^{1}$ E_Mail: hapsa_faktan@yahoo.co.id \\ ${ }^{2}$ E_Mail: yusry_ady@yahoo.co.id \\ ${ }^{3}$ E_Mail: nurhaedajasman@yahoo.co.id
}

\begin{abstract}
Abstrak: People rural same have local, it is one of species livestock not RAS (BURAS). Purpose have is to increase knowladge people so that residue farm to become food livestock. Raise in ceneral do traditional that is left prowl without food and stable. Raise to can do that semi intensive or intensive. Semi intencive is left during in the day and stabled in the night, while so that intencive is stabled all day and food although drink can control. For overcome problem society in raise the so do activity mixed woof herbal to livestok. This Acitivity do in kelurahan Ujung, kecamatan Lilirilau, kabupaten Soppeng South Sulawes. The target this activity are increase scale ownership, can exploited a material local as wooflivestock and surface this activity are increase knowladge and income sociaty.
\end{abstract}

Keyword: woof herbal, chicken local.

\section{PENDAHULUAN}

Kondisi masyarakat dipedesaan pada umumnya memelihara ayam kampung. Kondisi ini dapat diamati di desa-desa khususnya di Desa marossa Kelurahan Ujung, dimana hampir semua masyarakat memelihara ayam kampung sebagai hewan peliharaan. Ayam kampung dipelihara dengan tujuan diantaranya dengan memelihara ayam limbah rumahtangga yang berupa sisa-sisa makanan dan limbah sayur dapat diberikan kepada ayam sehingga tidak dibuang percuma. Pengembangan usaha ternak ayam kampung diharapkan mampu mengembangkan keterampilan masyarakat, serta mampu meningkatkan pendapatan. Tujuan dari kegiatan ini yaitu membrikan pengetahuan tambahan masyarakat dalam mengelola usaha ternak ayam kampung karena selama ini pemeliharaan ternak dilakukan secara tradisional. Dengan memelihara ternak limbah rumah tangga dapat dimanfaatakan sebagai pakan ternak. Selain itu, petani dapat memanfaatakan tanaman jagung sebagai pakan utama untuk ternak mereka. Dengan pengembangan ternak ayam kampung ditujang dengan pakan herbal sistem pemeliharaan ternak menjadi tertata dan masyarakat mampu mengembangkan peternakan berbasis organik.

Beternak ayam kampung memiliki banyak potensi, terutama pakan lokal yang tersedia disekitar peternka. Menurut Suryana (2013), bahwa untuk memelihara ternak ayam kampung sangat mudah. Keuntungan yang dapat diperoleh yaitu dengan mensiasati mahalnya pakan komplit, maka kita dapat menyusun komposis pakan ternak dari bahan-bahan yang ada disekitar peternakan.

\section{METODE DAN BAHAN}

Secara rinci metode kegiatan untuk membantu mitra dapat diuraikan sebagai berikut:

\section{Lokasi Kegiatan}

Kegiatan pengabdian tentang penggunaan bahan herbar untuk ayam kampung dilaksanakan pada kelurahan Ujung, kecamatan Lilirilau, kabuparen Soppeng. Kegiatan ini melibatkan 
kelompok tani jagung dan diharapkan petani dapat mengelola ternak mereka dengan baik. Kegiatan yang dikembangkan diharapkan dapat menambah pendapatan petani.

\section{Manajemen pemeliharaan ternak ayam dengan baik}

Metode pemeliharaan sangat mempengaruhi perkembangan ternak, mulai dari pemberian pakan sampai ke penanganan penyakit. Sebaiknya ternak dikandangkan secara intensif agar dapat dikontrol pakan serta penykitnya. Hal ini sesuai dengan nuryadi dan tawardi (2012) yang mengatakan bahwa Pemeliharaan ayam kampung secara intensif dapat meningkatkan produksi, mencegah wabah penyakit, memudahkan dalam tatalaksana pemeliharaan dan kontrol produksi. Pada saat ini ayam kampung dapat dipelihara seperti ayam ras pedaging, baik pengelolaan kandangnya, pemberian pakan dan air minumnya, penanganan kesehatan-nya, pencatatannya maupun pemanenannya. Oleh karena itu, kegiatan yang akan dilakukan pada mitra IbM yaitu sebagai berikut:

1. Memilih bibit ternak ayam yang akan dipelihara (akan digunakan bibir ayam kampong super, bibitnya dapat diperoleh dengan skala banyak serta pertumbuhan cepat)

2. Pemanfaatan bahan baku local untuk pakan ternak, seperti jagung dan dedak (dilokasi mitra kebanyak petani menanam jagung, dan harganya murah)

3. Pemanfaatan bahan baku local sebagai pakan herbal tambahan untuk ternak ayam (digunakan rebusan daun papaya untuk minum ayam, jahe, sere, maupun lengkuas digunakan untuk mencampur pakan)

\section{Metode pemeliharaan ternak ayam}

1. Bibit ayam (DOC) yang baru datang, dimasukkan kedalam kandang khusus (biasanya masi digunakan lampu untuk menjaga suhu, disini sudah diberi air rebusan daun papaya dan pakan)

2. Setelah dua minggu dipindahkan pada kandang pembesaran

3. Setelah umur 4 minggu ayam bisa di umbar agar ayam mampu mencari makan sendiri (namun dikontrol, ayam dilepas pada jam 10 pagi dan dikandangkan kembali pada jam 5 sore (metode semi intensif))

4. Setelah umur empat sampai lima bulan ternak sudah di jual.

\section{Pengolahan Pakan Herbal}

Komposisi campuran pakan herbal yang digunakan, yaitu:

1. Jahe

2. Kunyit

3. Sere

4. Lengkuas

5. Temu lawak

6. Bawang Putih

7. Yahult (sebagai fermentor)

Cara pembuatan campuran pakan herbal untuk ternak ayam, yaitu:

Semuan bahan jahe, kunyit, sere, lengkuas, temu lawak, bawang putih ditimbang sebanyak 1 $\mathrm{kg}$, kemudian bahan kesemuanya dihalurkan menggunakan mesin blender dan dicampur air sebanyak 2 liter. Campuran bahan tersebut kemudian dimasukkan dalam botol dan dicampur dengan yakult. Yakult pada campuran ini berfungsi sebagai fermentor, untuk mengurai kandungan yang terdapat di dalam bahan 
pencampur pakan. Setelah itu, difermentasikan selama 2 minggu. Setelah dua minggu, bahan siap dicampurkan pada minuman maupun makanan ternak ayam kampong.

\section{HASIL DAN PEMBAHASAN}

Kondisi ini dapat diamati di desa-desa khususnya di desa marossa kelurahan ujung, dimana hampir semua masyarakat memelihara ayam kampung sebagai hewan peliharaan. Ayam kampong dipelihara dengan tujuan diantaranya dengan memelihara ayam limbah rumah tanggan yang berupa sisa-sisa makanan dan limbah sayur dapat diberikan kepada ayam sehingga tidak dibuang percuma. Ayam kampung merupakan salah satu jenis ayam buras (bukan ras). Jenis ayam ini dapat dibedakan dari ayam ras berdasarkan warna bulunya yang sangat beragam, mulai dari warna putih, kuning, kemerahan, hitam, abu-abu dan yang paling banyak adalah kombinasi dari warna-warna tersebut. Selain itu, bentuk badan ayam kampung relatif lebih kecil dan penampilannya lebih lincah. Pada umur yang sama, jenis ayam ini mempunyai bobot badan yang lebih rendah dari pada ayam ras. Memang, salah satu ciri khas ayam kampung adalah sifat genetisnya yang tidak seragam seperti warna bulu, ukuran tubuh dan kemampuan produksinya.

Kendala pemeliharaan ayam kampung yaitu tidak adanya minat masyarakat untuk mengembangkan peternakan usaha ayam kampung, manajemen pemeliharaan yang masih secara tradisinal, penanganan kesehatan yang sangat minim, serta masyarakat tidak memandang ayam kampung ini memiliki prospek yang dapat dijadikan usaha sampingan dalam membantu prekonomian keluarga. Ditambahkan oleh Fatih (2013) bahwa pemeliharaan secara sistem tradisional, menyebabkan produksi telur ayam buras sangat rendah, \pm 60 butir/tahun/ekor. Berat badan pejantan tak lebih dari $1,9 \mathrm{~kg}$ dan betina \pm $1,2 \sim 1,5 \mathrm{~kg}$, maka perlu diintensifkan. Pemeliharaan yang intensif pada ayam buras, dapat meningkatkan produksi telur dan daging, dapat mencegah wabah penyakit dan memudahkan tata laksana.

Prospek memelihara ayam kampung sangat besar. Hal tersebut didukung dengan telah banyak dipelihara baik oleh peternak maupun masyarakat umum sebagai usaha untuk pemanfaatan pekarangan, pemenuhan gizi keluarga, menyalurkan hobi, peningkatan pendapatan dan bahkan sebagai usaha komersial. Pada umumnya, dahulu ayam kampung dipelihara secara tradisional (ekstensif), yaitu ayam dilepas begitu saja, tanpa disediakan kandang, pakan dan air minum oleh peternak. Seiring dengan perkembangan ilmu pengetahuan dan teknologi, ayam kampung mulai dibudidayakan dan dikembangkan baik secara semi intensif maupun intensif. Pemeliharaan ayam kampung secara semi intensif dilakukan dengan cara ayam pada pagi hari setelah diberi makan dilepas, baru kemudian pada sore hari masuk ke dalam kandang. Sedangkan pemeliharaan secara intensif dilakukan dengan cara ayam dikandangkan sepanjang hari, semua aktivitas dibawah pengelolaan peternak.

Ternak ayam kampung super menjadi salah satu jawaban dari permasalahan para peternak akan lambatnya pertumbuhan ayam kampung. Berbeda dengan ayam broiler yang bisa panen dalam waktu 40 hari saja. Ayam kampung super 
atau ayam kampung super memiliki pertumbuhan yang cukup pesat dibandingkan dengan ayam kampung biasa meski lebih lama jika dibandingkan ayam broiler. Dalam masa pemeliharaan 45 sampai 60 hari ayam kampung super sudah bisa dipanen. Joko Widodo (2013) menyatakan bahwa keuntungan beternak ayam kampung super ini selain angka kematian (mortalitas) yang rendah dengan rasa daging yang sama dengan ayam kamung asli, juga cara pemeliharaan sangat mudah, tidk menyita wktu dan tenaga. Dari segi harga jual, ayam kampung harganya lebih tinggi dibandingkan dengan ayam broiler (ayam potong), berkisar dari 20 ribu sampai 30 ribu hidup per kilogram dan pertumbuhannya lebih cepat.

Untuk membantu masyarakat khususnya mitra IbM yaitu Iskandar dan Alimuddin dalam memelihara yaitu meramu pakan herbal untuk ayam kampung super. Semua bahan baku untuk pakan ayam diperoleh dari sumber daya yang ada didaerah tersebut diantaranya jagung, dedan, daun papaya, jahe, maupun lengkuas. Keuntungan pakan herbal dan pakan local yaitu, harganya tidak mahal, sudah tersedia di sekitar kandang mitra IbM, pengelolaannya mudah, menjaga daya tahan ternak ayam, limbahnya tidak berbau serta pertumbuhan ternak lebih pesat. Maryuki (2013) menyatakan bahwa Keunggulan ini didapat sebagai hasil ternak dengan cara beternak yang lain dari peternak pada umumnya yaitu sistem organik. Artinya semua proses produksi mulai dari bibit hingga pemasaran tidak mengandung bahan kimia dan rekayasa genetika seperti inseminasi buatan (kawin suntik). Dengan pemanfaatan herbal sebagai ransum dan antibiotik, serta tidak digunakan berbagai unsur kima, diharapkan kadar lemak dalam daging hanya sekitar $10 \%$ dan kandungan protein daging dan telur adalah sebesar $70 \%$. Lebih tinggi dari ayam lain yang hanya sekitar $20 \%$.

Hasil yang telah dicapai dari kegiatan pengabdian ini adalah tersedianya kandang percontohan untuk pengembangan ayam kamupng yang dapat menampng kurang lebih 250 ekor ayam kampung. Selain itu, peternak juga memperoleh tambahan pengetahuan tentang budidaya ternak ayam kampung secara semi intensif.

\section{Produksi Telur}

Pemanfaatan campuran pakan herbal sangat membantu peternak, selama 6 bulan aplikasi pakan herbal produksi telur setiap betina meningkat 30 persen.

- Ternak tanpa perlakuan (hanya menggunakan pakan dedak dan limbah rumah tangga) diperoleh produksi telur hanya $8-10$ butih, setiap periode bertelur

- Pemberian campuran pakan herbal pada minuman dan pakan ternak ayam, diperoleh produksi telur 11 - 15 butir setiap priode bertelur.

\section{Perkembangan Ternak}

Pencampuran pakan herbal pada makanan dan minuman ternak ayam, memberikan perkembangan yang signifikan pada ternak. Dimana terbukti dari nafsu makan ternak meningkat, dilihat dari sisa pakan yang diberikan pada pagu dan sore hari. Bulu ternak yang mengkilat, pertambahan berta badan yang signifikan. (rata-rata pertambahan berat badan 0,7 $\mathrm{kg} / 60$ hari). 


\section{Ketahanan terhadap Penyakit}

Penyakit yang paling sering meyerang ternak ayam kampong yaitu tetelo dan munculnya benjolan pada bagian kelopak mata. Selain itu, sifat kanibalisme dimana ternak yang luka akan selalu dipatuk oleh ternak yang lain khususnya dipatuk pada bagian yang luka.

- Pemberian campuran pada pakan dan minuman ternak akan menambah daya tahan ternak ayam kampung dari penyakit tetelo, serta ternak mencadi lincah.

- Untuk menghindari luka pada ternak yang sakit agar tidak dipatuk ternak lain, yaitu dilakukan perlakuan dengan mengolesi atau membasuk lukan pada ternak menggunakan campuran pakan herbal.

\section{SIMPULAN}

Berdasarkan hasil kegiatan yang telah dilakukan maka dapat ditarik kesimpulan:

1. Bahan campuran pakan herbal menrupakan bahan-bahan yang diperoleh di sekitar peternak, yang dengan mudah diperoleh dan tersedia dalam jumlah banyak.

2. Fermentasi pakan herbal menggunakan media yakult, yang diharapkan memiliki kandungan bakteri yang cukup untuk mengurai kandungan yang yang ada di dalam bahan-bahan herbal.

3. Pemberikan campuran pakan herbal pada minuman dan makan ternak akan menigkatkan produksi telur, meningkatkan pertambahan berat badan serta menjaga ketahanan tubuh pada ayam, agar terhindar dari penyakit.
}

\section{DAFTAR PUSTAKA}

Fatih, 2013. Beternak Ayam Kampung. http.//fatihio.biz/beternak ayam kampung.html. (diakses april 2014)

Joko widodo. 2013. Analisis Usaha Beternak Ayam Kampung Super. www. Google.com (diakses januari 2013)

Maryuki. 2013. Ayam Kampong Organik. Ternak Ayam Kampng.com (diakses april 2014)

Nuryati dan Tawardi. 2012. Intensifikasi Ayam Kampung. www. Google.com (diakses maret 2014)

Suryana Dayat, (2013). Alamtani. Agribisnis dan Hobi. Diakses Google tahun 2013. 